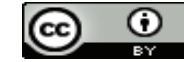

\title{
Teaching English as an additional language for social participation: digital technology in an immersion programme
}

Ensino de inglês como língua adicional para a participação social: tecnologias digitais em um programa de imersão

Lucas Moreira dos Anjos Santos*

English Connect, Monash University

Melbourne, Victoria / Austrália

Michele Salles El Kadri**

Departamento de Letras Estrangeiras Modernas, Universidade Estadual de Londrina Londrina, Paraná / Brasil

Raquel Gamero***

Centro de Letras, Comunicação e Artes, Universidade Estadual do Norte do Paraná Cornélio Procópio, Paraná / Brasil

Telma Gimenez****

Departamento de Letras Estrangeiras Modernas, Universidade Estadual de Londrina Londrina, Paraná / Brasil

\begin{abstract}
This paper analyses conceptualizations of digital technology use that are aligned with sociocultural pedagogies of language learning, proposing a framework for developing sociocultural language pedagogies through digital technology use and presenting the language education workshops offered for high school students as embodying the principles of such a perspective. The paper is grounded on a sociocultural perspective of learning. Data gathering occurred in the New Talents Program, which is the background of the instructional material developed for the immersion week "Digital technologies and English language learning". We conclude by discussing some opportunities and challenges for sociocultural pedagogies of language learning through digital literacies.
\end{abstract}

KEYWORDS: teaching English; digital technology; social participation.

\footnotetext{
* lucas.santos@monash.edu

**mielkadri@hotmail.com

*** raquelgamero.rg@gmail.com

**** tgimenez@uel.br
} 


\begin{abstract}
RESUMO: Este artigo objetiva analisar as conceitualizações do uso da tecnologia digital alinhados às pedagogias socioculturais do aprendizado de línguas; propor um quadro para desenvolvimento das pedagógicas socioculturais por meio do uso das tecnologias digitais e apresentar e discutir oficinas de línguas oferecidas a alunos do ensino médio sob esse mesmo viés. Desse modo, este artigo está amparado pelas teorias socioculturais para o aprendizado de línguas. Os dados foram coletados por meio do Programa Novos Talentos. Concluímos o artigo discutindo as oportunidades e desafios para as pedagogias socioculturais para o aprendizado de línguas por meio de letramentos digitais.
\end{abstract}

PALAVRAS-CHAVE: ensino de inglês, tecnologia digital, participação social.

\title{
1 Introduction
}

Learning is not a neutral or an uncontested concept. Different epistemologies support different perspectives of learning, which, in turn, imply different roles for teachers, learners and how knowledge comes into production. To assume a certain perspective on learning means privileging some capabilities that learners should develop. In this paper, the concept of learning we adopt derives from a sociocultural perspective. Learning thus happens when individuals participate in socially situated activities that mediate relations, practices and actions. According to Wenger (2009, p. 210), learning has to do with social participation in which "participation here refers not just to local events of engagement in certain activities with certain people, but to a more encompassing process of being active participants in the practices of social communities and constructing identities in relation to these communities."

Such a view on learning entails that teachers create opportunities for learners to engage and critically appraise different practices constituting societies. More importantly, it points out to the need to avoid abstract and decontextualized learning that makes little or no sense for learners. If learning is a sociocultural activity itself, learning additional languages, from such a perspective, is no different.

However, it is still usual to find language learning pedagogies that focus solely on memorizing and producing decontextualized language structures out of the social, cultural and political contexts in which language practices take place. Sociocultural views of literacy (STREET, 1984; 2013; GEE, 1991; 2015; LANKSHEAR; KNOBEL, 2011), on the other hand, highlight the ways in which language use is embedded into the social contexts of which they arise, are part of and constitute. Similarly, the advent of digital technologies and the ease with which people can produce, consume 
and manage multimodal texts pose new challenges for language learning pedagogies, which focus solely on print-based literacies.

During the years of 2012 and 2013, we designed and implemented a series of workshops for high school students that focused on digital technologies and English language learning. Such workshops were planned as part of an immersion week and occurred as extracurricular activities in the New Talents Program sponsored by the CAPES Foundation. Based on this experience, in this paper, we aim to:

- analyze conceptualizations of digital technology use that are aligned with sociocultural pedagogies of language learning;

- propose a framework for developing sociocultural language pedagogies through digital technology use;

- present the language education workshops offered for high school students as embodying the principles of sociocultural pedagogies of language education through digital technology use.

The remainder of the paper is organised into three sections. In the first part, we discuss theoretical perspectives on digital technology use and what their assumptions of digital technologies are as well as their roles in everyday life. In the second part, we describe the New Talents Program, which is the background of the instructional material developed for the immersion week "Digital technologies and English language learning", as well as detail and exemplify a didactic proposal via the instructional material produced. Finally, we conclude by discussing some opportunities and challenges for sociocultural pedagogies of language learning through digital literacies, based on our experience.

\section{Theoretical perspectives on digital technology use and language learning}

The use of the expression digital technologies is supported by three basic arguments. First, qualifying contemporary technologies as digital highlights the technical process by which information is currently produced, transformed, shared and consumed. Digitization relies on the technical characteristics of the binary code of computers that allow data to be processed and transformed into bytes. Second, because of digitization, a number of different electronic devices can now converge and facilitate the integration of old and new media. The process of convergence allows 
more room for hybrid relationships between corporate media and the individuals who use these media. Third, the technical conditions of digital technologies also allow people to engage with new media in different scales of participation. These new patterns blur traditional distinctions between production and consumption, and authorship and readership (VAN DIJK, 2012; MILLER, 2011; JENKINS, 2008).

However, the previous account of the socio-technical characteristics of digital technologies, and some of their affordances, hinders more complexly social and political relations. Such relations refer to how individuals use, adapt and appropriate these technologies for mediating their everyday social practices. To account for the cultural processes at stake when people use digital technologies for their own creative and critical purposes, this chapter needs more socially grounded definitions. One might then ask what the unintended social and political consequences of digital technology use are in the globalized societies of the $21^{\text {st }}$ century.

Discourses about digital technology use have been branded with either celebratory or pessimistic accounts focusing on the changes such uses may trigger in people's everyday lives. On the one hand, digital technologies are celebrated as providing young people with disruptive, participatory and creative experiences. On the other hand, digital technologies are blamed for negatively affecting young people's writing abilities and for making young people too reliant on search engines for anything they need. A number of scholars have challenged such binary claims that represent digital technology as an agent of change per se (WARSCHAUER, 1998; BUZATO, 2006; BUCKINGHAM, 2007; 2013; SNYDER, 2009; SELWYN, 2010; BRAGA, 2010). Warschauer (1998), for example, proposed three approaches to unpack the assumptions that support digital technology use in educational contexts: (a) determinist, (b) instrumental and (c) critical approaches, presented in Table 1. 
TABLE 1 - Approaches to digital technology based on Warschauer (1998)

\begin{tabular}{l|l|l}
\hline Approach & \multicolumn{1}{|c|}{ Conception } & Recent example from the media \\
\hline Determinist & $\begin{array}{l}\text { A computer and other technologies, when } \\
\text { incorporated in specific situations, bring } \\
\text { about determined outcomes. }\end{array}$ & $\begin{array}{l}\text { "How smartphone apps are revolutionizing } \\
\text { language learning" (The Conversation) }\end{array}$ \\
\hline Instrumental & $\begin{array}{l}\text { A computer and other technologies are } \\
\text { simply tools that can be used by individuals } \\
\text { for their own purposes in any context. } \\
\text { reshaping teaching" (The Telegraph) }\end{array}$ & $\begin{array}{l}\text { "Three ways to use iPads in the language } \\
\text { classroom" (The Guardian) }\end{array}$ \\
\hline Critical & $\begin{array}{l}\text { A computer and other technologies are } \\
\text { part of larger social struggles in different } \\
\text { societies. Technologies can be have in-built } \\
\text { and preferred uses, but individuals can } \\
\text { challenge and adapt technologies for their } \\
\text { own purposes. Technologies are enmeshed } \\
\text { with social and political struggles and the } \\
\text { outcomes of technology incorporation } \\
\text { vary from context to context. }\end{array}$ & $\begin{array}{l}\text { "The technology a silver bullet for language } \\
\text { learn a language" (Forbes) }\end{array}$ \\
\hline
\end{tabular}

The importance for language teachers to approach digital technology from a critical approach is that it articulates both the technical characteristics of digital technologies and the social and political uses associated with their uses when people engage in digitally mediated practices. Such a perspective accounts for a more nuanced social view on how individuals appropriate and shape different technologies when engaging in digitally mediated activities. As Buckingham argues (2013, p. 8),

The key idea here is that technology has 'affordances' - it makes some things possible, but it prevents other things. However, what happens with technology also depends on people's intentions and on the social context - and sometimes technology is used and adapted in unexpected ways.

These attempts for a more holistic view of digital technology use allow language teachers to prevent merely technical understandings of digital media and their roles in language learning pedagogies. In the elaboration of language learning materials, teachers produce a group of coherent activities that pedagogically represent the theoretical foundations that inform their language learning theories and assumptions. When designing the workshops 
for the immersion week "Digital technologies and English language learning", all the authors who produced workshops had the autonomy to decide the language learning approaches that best suited their purposes. As a result, the instructional material produced represented a variety of approaches to language learning.

To assume such a diverse, situated and multiple theoretical perspective towards the use of digital technologies for language learning and teaching can also be related to Kumaradivelu's (2001) postmethod pedagogy. According to Kumaradivelu (2001), a postmethod pedagogy consists of three interrelated principles: particularity, practicality and possibility. The particularity principle highlights "a context-sensitive, locationspecific pedagogy that is based on a true understanding of local linguistic, sociocultural and political particularities" (p. 544). The practicality principle highlights the rejection of "the artificial dichotomy between theorists who have been assigned the role of producers of knowledge and teachers who have been assigned the role of consumers of knowledge" (p. 544). On the contrary, the principle of particularity encourages "teachers to theorize from their practice and practice what they theorize" (p. 545). Finally, the possibility principle highlights the rejection of "the narrow view of language education that confines itself to the linguistic functional elements that are obtained inside the classroom" (p. 545). Rather, the possibility principle, anchored on Paulo Freire's ideas (1992), stresses "the socio-political consciousness that participants bring with them to the classroom so that it can also function as a catalyst for a continual quest for identity formation and social transformation" (p. 545). Kumaradivelu's (2001) postmethod principles fit well in our approach for developing language learning pedagogies through digital literacies. A postmethod perspective allows researchers and teachers to transit among different theoretical perspectives and pedagogies and analyse how to promote better conditions for language learning and teaching.

Drawing on a postmethod disposition, we adopted some principles that can shape sociocultural language learning approaches through digital literacies. The principles described in Table 2 emerged from our conceptualization of sociocultural approaches to language, literacy and education that have gained momentum since the late eighties (HEATH, 1983; STREET, 1984, 2013; GEE, 1991, 2015). Language education involves not only learning 'a language' but also entails the changing of practices, identities and representations in relation to the world. In his often-cited 
work, Street (1984) proposes an ideological model for literacy studies. Such a model acknowledges that language practices are invested with the social values and perspectives of specific groups of which they arise. It follows that literacy is a contested practice and what counts as 'important', 'legitimate', 'proper' literacy is always problematic and depends on the sociocultural worlds and views of those who engage in such practices.

Several Brazilian researchers have engaged in a sociocultural view on literacy and digital technologies and produced insightful perspectives on the different roles digital literacy practices can assume in a society marked by inequalities, such as that of Brazil (ARAÚJO; DIEB, 2009; ARAÚJO; LIMA, 2010; BALADELI; FERREIRA, 2012; BRAGA, 2007; 2010; BUZATO, 2009; 2010; FERREIRA, 2012; JORDÃO, 2007; MOITA LOPES, 2010; MONTE-MÓR, 2007; 2009; PAIVA, 2007; ROJO, 2007; among others). Braga (2010) has argued that the use of digital technologies by disadvantaged groups do not change their status when it comes to social participation but nevertheless may provide potentially new ways of engaging in and transforming predominant discourses. Based on a neo-Gramscian perspective, Braga highlights that, in order to promote more equitable and democratic access to social goods by different social groups, including the access to digital technologies, one has to be able to rethink his or her own social position and privileges. The author advocates that one of the main challenges for digital literacy researchers is to find ways of using these new practices so that they become more accessible to everybody and transform dominant practices. Anchored on a critical social awareness perspective deriving from Freire (1992), Braga (2007, p. 183) advocates that "what makes technologies good or bad is the use that social communities make of them, [so] it is important to move beyond reproductive and deterministic positions and inquire how the power of digital technologies can be critically exploited to promote more progressive ends."

More recently, Braga and Vovio (2015, p. 60-61) argue that:

$[\ldots]$ it seems essential that we consider a school education that includes the resources offered by digital technologies as an extra technology used to appropriate existing knowledge, as well as the production, revision and socialisation of new cultural perspectives. Therefore, it is necessary to integrate into the schooling practice new digital literacy practices that demand the participation through the mobilisation of multimodal genres and the knowledge of how these texts work in different situations, 
without disregarding the tensions that power relations engender in these interactions. ${ }^{1}$

Braga and Vovio's conceptualization of digital technologies and digitally-based pedagogies highlights two important consequences for additional language learning. First, using digital technologies and the digital literacy practices associated with their use for language learning pedagogies means to explore the complex social, economic and cultural dimensions involved in issues of access, equity and critical social awareness for language learners. Second, it also points to the roles language teachers might assume in developing digitally-based pedagogies to decrease inequality gaps in societies, such as those of Brazil (BRAGA, 2007; 2010; BRAGA, VOVIO, 2015).

In a similar vein, Monte Mór (2009) discusses how social life in contemporary times have undergone changes in relation to the global capitalist system and the ways people conceptualize and produce meanings about their engagement in social practices. The author advocates that additional language teachers should foreground their pedagogical practices in philosophical epistemologies deriving from digital and critical literacies. Learning additional languages from an epistemology of digital and critical literacies may require from teachers and educational systems an ongoing evaluation of how their practices and understandings emerging from such practices take shape in classrooms (BRAGA, 2007; MONTER MOR, 2009). For students to engage in literacy practices and critically evaluate the beliefs, values, ideologies and power flows shaping such practices, foreign language pedagogies need to be questioned and submitted to scrutinised examination. As Monte Mór (2009, p. 188) states "this may be an alternative to deconstruct the belief that foreign languages as disciplines are misplaced in the school curriculum; and to construct a plan to enable the school to accomplish a meaningful proposal of such teaching."

\footnotetext{
${ }^{1}$ Our translation: “ [...] parece ser essencial pensarmos uma formação escolar que inclua os recursos oferecidos pelas TDICs como mais uma tecnologia a serviço da apropriação de conhecimentos existentes, assim como produção, revisão e socialização de novas perspectivas culturais. Para tanto, é necessario incorporar as práticas escolares, novas práticas de letramento digitial que impliquem a participação por meio da mobilização de gêneros multimodais e conhecimento de como esses textos funcionam nas mais diferentes situações, sem eximir-se de explorar as tensões que as relações de poder impõem nessas interações."
} 
These conceptualisations of additional language teaching through digital literacies highlight the importance of language pedagogies that combine both criticality and creativity. The critical component of sociocultural language pedagogies through digital literacy questions power relations and underlying mechanisms by which digital technology is sustained economically. The creative component of sociocultural language pedagogies through digital literacy empowers learners to envision other possibilities, and engage in the reconstruction of new practices.

Anchored on these theoretical perspectives of digital technology use, this paper describes principles that could guide additional digitally-based language learning pedagogies. The principles are framed under three broad categories: tools, meaning-making practices and identities, as can been seen in Figure 1. The choice of such overarching categories relies on the mutual relationship there is among individuals' engagement in meaning-making via the mediation of specific cultural tools and the identities they perform, as they represent and (re)create their worlds.

FIGURE 1 - Three frames to look at digitally based language learning based on Jones and Hafner (2012)

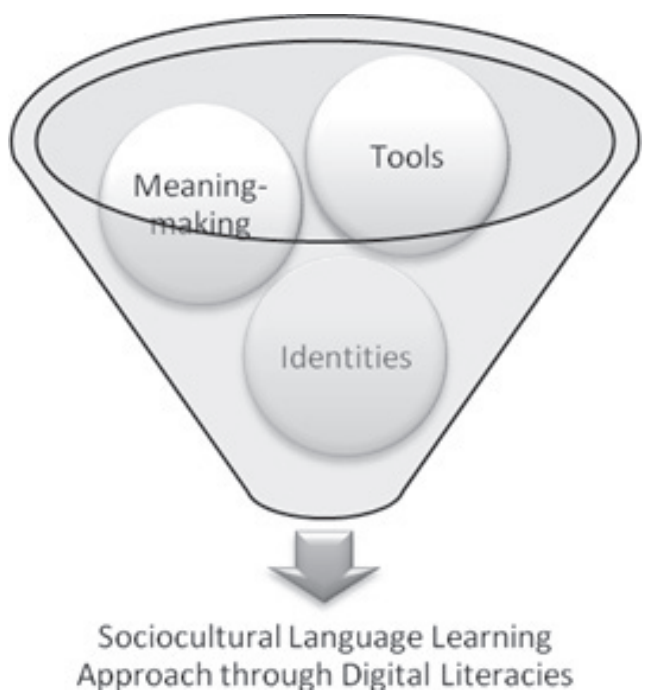

These principles are transient because they offer a situated analytical perspective into the instructional material produced for the immersion week "Digital technologies and English language learning". In this light, these 
principles are (re)presented in Table 2 and serve as a heuristic assessment grid of the way we envisage a sociocultural perspective on language learning through and with digital literacies.

TABLE 2 - Principles for designing digitally-based language learning pedagogies

\begin{tabular}{l|l}
\hline \multicolumn{1}{c}{ Principle } & \multicolumn{1}{c}{ Tools } \\
\hline $\begin{array}{l}\text { 1. Digital technologies, as any human } \\
\text { production, are inherently social, } \\
\text { cultural and political. The uses people } \\
\text { make of digital technologies are } \\
\text { intertwined with different interests, } \\
\text { values and agendas. }\end{array}$ & $\begin{array}{l}\text { 1a. How are digital technologies represented (as neutral, } \\
\text { pragmatic or political tools)? } \\
\text { 1b. Is digital technology represented in a deterministic } \\
\text { way? } \\
\text { 1c. Are digital technologies represented as imbued with } \\
\text { action capacities? }\end{array}$ \\
\hline $\begin{array}{l}\text { 2. Digital tools relate both to global } \\
\text { and local perspectives. They are } \\
\text { plural, mobile and assume different } \\
\text { values in different sociocultural } \\
\text { situations. }\end{array}$ & $\begin{array}{l}\text { 2a. What digital tools are featured in the material? } \\
\text { 2b. Are there digital tools that afford different types of } \\
\text { engagement? }\end{array}$ \\
\hline
\end{tabular}

\begin{tabular}{l|l}
\hline \multicolumn{2}{c}{ Meaning-making Practices } \\
\hline \multicolumn{1}{c}{ Principle } & \multicolumn{1}{c}{ Possible questions } \\
\hline $\begin{array}{l}\text { 3. Digital literacies are situated } \\
\text { meaning-practices mediated by digital } \\
\text { technologies and enmeshed with } \\
\text { values and interests of particular } \\
\text { groups. }\end{array}$ & $\begin{array}{l}\text { 3a. What are the digital literacy practices and events } \\
\text { focused on in the material? } \\
\text { explored? }\end{array}$ \\
$\begin{array}{l}\text { 3c. Are the semiotic resources analysed in terms of the } \\
\text { partiality and value-laden nature of meaning-practices? }\end{array}$ \\
$\begin{array}{l}\text { produce and represent knowledge } \\
\text { through the assemblage of different } \\
\text { modes. }\end{array}$ & $\begin{array}{l}\text { 4a. How are different modes explored? } \\
\text { 4c. Are there a balanced exploration of different modes? } \\
\text { and question how different modes are combined to } \\
\text { produce preferred meanings? }\end{array}$ \\
\hline $\begin{array}{l}\text { 5. Digital literacy practices usually } \\
\text { encourage individuals to collaborate } \\
\text { and participate in knowledge } \\
\text { production. }\end{array}$ & $\begin{array}{l}\text { 5a. Are there opportunities for learners to collaborate } \\
\text { with each other and people from other locations? } \\
5 \text { b. What types of participation do the activities } \\
\text { encourage learners to engage in? }\end{array}$ \\
\hline $\begin{array}{l}\text { 6. Digital literacy creates dispositions } \\
\text { towards imagining alternative worlds. }\end{array}$ & $\begin{array}{l}\text { 6a. Are the worldviews presented open to challenges? } \\
\text { 6b. Do the activities encourage envisioning of alternative } \\
\text { practices? }\end{array}$ \\
\hline
\end{tabular}




\section{Identities}

\begin{tabular}{l|l}
\hline \multicolumn{1}{c|}{ Principle } & \multicolumn{1}{c}{ Possible questions } \\
\hline $\begin{array}{l}\text { 7. Learners are active meaning- } \\
\text { makers that engage in digital literacy } \\
\text { practices. }\end{array}$ & $\begin{array}{l}\text { 7a. Do the activities encourage learners to express and } \\
\text { share their own understandings of texts? } \\
\text { 7b. Are the learners required to engage in language } \\
\text { practices involving digital literacy? }\end{array}$ \\
\hline $\begin{array}{l}\text { 8. Learners understand that digital } \\
\text { literacy practices are inherently social } \\
\text { and political as with any meaning- } \\
\text { making practice. }\end{array}$ & $\begin{array}{l}\text { 8a. Do learners have opportunities to reflexively analyse } \\
\text { their own linguistic choices? } \\
\text { 8b. Are learners guided to understand their semiotic } \\
\text { choices represent a certain perspective? } \\
\text { 8c. How do the activities foster critical engagement with } \\
\text { ideas, positions and the values underlying them? }\end{array}$ \\
\hline $\begin{array}{l}\text { 9. Learners are open to analyse their } \\
\text { epistemic views. }\end{array}$ & $\begin{array}{l}\text { 9a. Are learners encouraged to question their own } \\
\text { assumptions? } \\
\text { 9b. Do the activities allow questioning of taken-for- } \\
\text { granted assumptions? }\end{array}$ \\
\hline $\begin{array}{l}\text { 10. Learners are co-producers of the } \\
\text { digital literacy curriculum. }\end{array}$ & $\begin{array}{l}\text { 10a. Are learners given the responsibility to choose what } \\
\text { digital media texts they want to produce? } \\
\text { 10b. Can learners choose the topic they wish to address } \\
\text { in their digital media texts? }\end{array}$ \\
\hline
\end{tabular}

\section{The New Talents Programme}

Within the scope of the National Policy for the Education of Schoolteachers, the Brazilian government issued a program aimed at strengthening university-school partnerships, entitled "Programa de apoio a projetos extracurriculares: Investindo em novos talentos da rede de educação pública para inclusão social e desenvolvimento da cultura" [Program to provide support for extracurricular projects: investing in new talents in state schools for social inclusion and the development of culture], New Talents, for short. ${ }^{2}$

The call for applications by universities interested in promoting the program objectives was opened in 2009 and suggested more integration between undergraduate, graduate programs and schools. Both teachers and

\footnotetext{
2 "Ferramentas tecnológicas para o desenvolvimento profissional e ensino-aprendizagem de língua inglesa" [Technological tools for professional development and teaching/learning of English].
} 
students could be targeted and involved in innovative activities that would take place in spaces such as universities dependencies, laboratories, advanced centers of study and research, museums and other institutions, including public and private companies. Many universities submitted proposals for courses and workshops during the school vacation period, so as not to interfere with the academic calendar.

Our institution submitted the Project entitled "Para inserção em um mundo globalizado: utilizando recursos tecnológicos no ensino e aprendizagem de inglês" [Towards inclusion in a globalised world: using technological tools for the teaching/learning of English"]. A 40 hour workshopfor schoolteachers in the Londrina region was designed and offered in 2012. The workshop delivery was based on materials ${ }^{3}$ developed for the facilitators with emphasis on digital genres (GAMERO; EL KADRI,; GIMENEZ, 2012). In 2013 the "Immersion Week" workshop was designed and implemented with high school students. During 5 days they had the opportunity to practice the English language in meaningful contexts, using digital technologies and focusing on areas relevant to their vocational choices.

\section{An overview of the didactic proposal}

The instructional material produced for the English immersion is characterised by varied approaches and practices to language learning. There were 18 workshops aimed at high school students that focused on different fields of knowledge. Table 3 provides an overview of the workshops that were produced, their goals and the digital practices in which students were prompted to join.

\footnotetext{
${ }^{3}$ The activities that compose each workshop can be accessed at <http://www.uel.br/ programas/novostalentos/pages/arquivos/Teaching_learning_S3.pdf>.
} 


\section{TABLE 3 - Overview of the workshops produced in the immersion week}

\begin{tabular}{|c|c|c|c|c|}
\hline & Field & Workshop & Main goal & Digital Practices and Resources \\
\hline \multirow{4}{*}{ 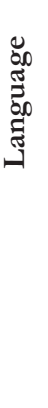 } & & $\begin{array}{l}\text { W1: What do you know } \\
\text { about languages? }\end{array}$ & $\begin{array}{l}\text { To become familiarized with the } \\
\text { possibilities of online language } \\
\text { learning through platforms. }\end{array}$ & $\begin{array}{l}\text { Learning languages through } \\
\text { online platforms; using online } \\
\text { dictionaries; reading web-based } \\
\text { information. }\end{array}$ \\
\hline & & W2: Slangs and Idioms & $\begin{array}{l}\text { To familiarize students with } \\
\text { common idioms in English. }\end{array}$ & $\begin{array}{l}\text { Consuming information } \\
\text { through online slide sharing. }\end{array}$ \\
\hline & & $\begin{array}{l}\text { W3: Sharing personal } \\
\text { information }\end{array}$ & $\begin{array}{l}\text { To share personal informal } \\
\text { through a visual profile. }\end{array}$ & $\begin{array}{l}\text { Using Twitter to ask personal } \\
\text { questions. }\end{array}$ \\
\hline & & $\begin{array}{l}\text { W4: Getting to know } \\
\text { each other }\end{array}$ & $\begin{array}{l}\text { To introduce oneself and talk } \\
\text { about personal questions. }\end{array}$ & $\mathrm{N} / \mathrm{A}$ \\
\hline \multirow{3}{*}{\multicolumn{2}{|c|}{ 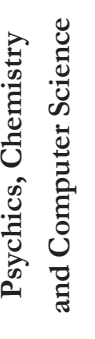 }} & $\begin{array}{l}\text { W5: Everything started } \\
\text { with the Big Bang }\end{array}$ & $\begin{array}{l}\text { To discuss scientific information } \\
\text { delivered through the web and its } \\
\text { suitability. }\end{array}$ & $\begin{array}{l}\text { Using online encyclopedias; } \\
\text { watching YouTube videos. }\end{array}$ \\
\hline & & $\begin{array}{l}\text { W6: Things happen for } \\
\text { a reason }\end{array}$ & $\begin{array}{l}\text { To understand how a volcano } \\
\text { works. }\end{array}$ & Watching YouTube videos. \\
\hline & & $\begin{array}{l}\text { W7: Machinery } \\
\text { mysteries }\end{array}$ & $\begin{array}{l}\text { To reflect on the value of } \\
\text { Computer Science in today's } \\
\text { world and learn vocabulary } \\
\text { related to technology. }\end{array}$ & Watching YouTube videos. \\
\hline \multirow{3}{*}{\multicolumn{2}{|c|}{ 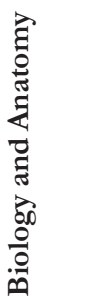 }} & $\begin{array}{l}\text { W8: Do you know } \\
\text { yourself inside out? }\end{array}$ & $\begin{array}{l}\text { To identify the parts of the } \\
\text { human body. }\end{array}$ & Watching YouTube videos. \\
\hline & & $\begin{array}{l}\text { W9: Curiosities about } \\
\text { our body }\end{array}$ & $\begin{array}{l}\text { To explore curiosities about the } \\
\text { human body. }\end{array}$ & $\begin{array}{l}\text { Navigating through digital } \\
\text { animations. } \\
\text { Online TV }\end{array}$ \\
\hline & & W10: Let's have fun & $\begin{array}{l}\text { To strengthen and apply the } \\
\text { body part vocabulary through } \\
\text { kinesthetic activities. }\end{array}$ & $\mathrm{N} / \mathrm{A}$ \\
\hline \multirow{3}{*}{\multicolumn{2}{|c|}{ 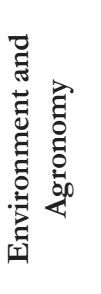 }} & $\begin{array}{l}\text { W11: The environment } \\
\text { and you }\end{array}$ & $\begin{array}{l}\text { To problematize human impacts } \\
\text { on the environment and to } \\
\text { reflect on our roles as citizens. }\end{array}$ & $\begin{array}{l}\text { Reading online webpages; } \\
\text { watching YouTube videos; } \\
\text { using online Dictionaries }\end{array}$ \\
\hline & & $\begin{array}{l}\text { W12: Let's talk about } \\
\text { sustainable agronomy }\end{array}$ & $\begin{array}{l}\text { To discuss overconsumption and } \\
\text { the environment. }\end{array}$ & $\begin{array}{l}\text { Reading online webpages; } \\
\text { watching You'Tube videos. }\end{array}$ \\
\hline & & W13: Eco-Cities & $\begin{array}{l}\text { To reflect on the impact of } \\
\text { our lifestyles on the urban } \\
\text { environment. }\end{array}$ & Reading online webpages. \\
\hline
\end{tabular}




\begin{tabular}{l|l|l|l}
\hline & W14: What's a museum? & $\begin{array}{l}\text { To prepare students for a tour at } \\
\text { the local historical museum. }\end{array}$ & $\begin{array}{l}\text { Searching for information } \\
\text { online. }\end{array}$ \\
\cline { 2 - 4 } & $\begin{array}{l}\text { W15: Do you know how } \\
\text { to read? Talking about } \\
\text { expression }\end{array}$ & $\begin{array}{l}\text { To perceive that there is ideology } \\
\text { in images and become aware } \\
\text { of one's own identity through } \\
\text { personal image projection. }\end{array}$ & $\begin{array}{l}\text { Watching You'Tube videos; } \\
\text { searching for information } \\
\text { online; taking an online } \\
\text { museum tour. }\end{array}$ \\
\cline { 2 - 5 } & $\begin{array}{l}\text { W16: Musical Cultures: } \\
\text { Marching bands and } \\
\text { brass bands }\end{array}$ & $\begin{array}{l}\text { To discuss music as a cultural } \\
\text { phenomena. }\end{array}$ & Watching YouTube videos. \\
\cline { 2 - 5 } & W17: $5,6,7,8-$ Action! & $\begin{array}{l}\text { To improve students oral skills } \\
\text { through theater acting games. }\end{array}$ & N/A \\
\cline { 2 - 5 } & W18: Acting & $\begin{array}{l}\text { To use language in an interactive, } \\
\text { spontaneous and risk-taking } \\
\text { environment. }\end{array}$ & Watching YouTube videos. \\
\hline
\end{tabular}

A glimpse into table 3 demonstrates that not all workshops have engaged with digitally based language learning practices. Similarly, it is clear that the workshops have tended to focus on a limited view of social participation through digital practices - a more instrumental approach to digital technology as proposed by Warschaeur (1998). The participation of individuals in digital practices can be understood through a continuum as represented in Figure 2.

FIGURE 2-Conceptualizing social participation in digital practices

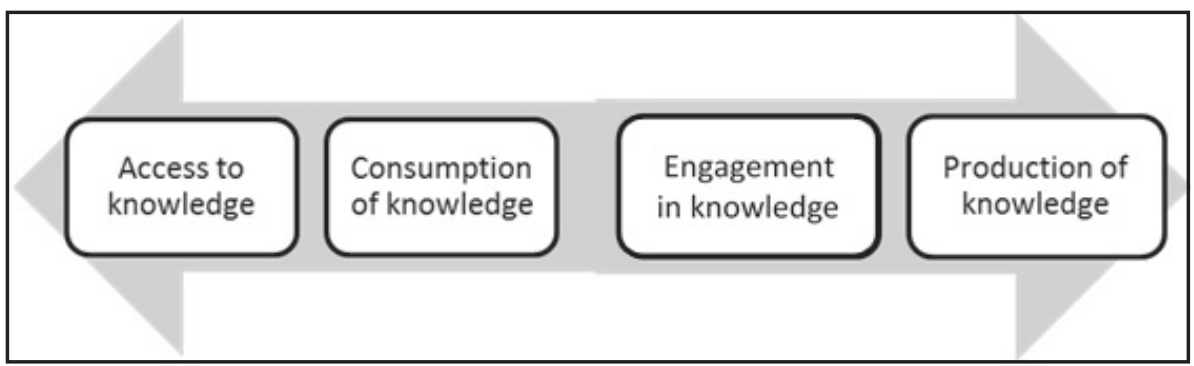

Social participation in digital practices, therefore, goes through accessing and consuming knowledge, from one end, to engaging and producing knowledge, at the other end (BRAGA and VOVIO, 2015). The workshops focused more on the access and consumption of knowledge end of the continuum than on the engagement and production knowledge end. Such differences are accounted by the number of language teachers that designed workshops and their soundly preferred approaches to 
language learning, based on what they conceptualized as the local needs of the workshop participants. Likewise, the general guidelines that shaped the production of the instructional material have not been enforcing or constraining and have allowed for such a varied uptake of approaches.

In addition to the 18 workshops presented in Table 3 , the high school students also engaged in a hands-on project that functioned transversally to link the different fields of knowledge and the use of digital technologies for creative and critical purposes. This hands-on project aimed to guide students to produce their own glogs, ${ }^{4}$ a digital poster that allows the use of different modes. This tool was selected by its potentiality to increase the students' access to multimodal text production and the exploration of several technological resources. The following sections focus on the analysis of the hands-on project based on the principles presented in Table 2.

\section{The use of tools in the hands-on project with glogs}

The authors of the hands-on project explored digital technology as situated and part of human production, especially as a cultural phenomenon. It is feasible to claim that this section of instructional material attempts to pursue a critical approach to digital technology, though in a limited way (WARSCHAUER, 1998).

Figures 3 and 4 represent how digital technology has been mainly presented to students as pragmatic tools. In fact, in Figure 3, there are activities that focus more specifically on the incorporation of linguistic and discursive resources to the students' existing linguistic repertoires. In addition, in Figure 4, there are activities that are pragmatic in terms of eliciting integrated tools and language resources.

\footnotetext{
${ }^{4}$ According to the platform used with the students, a glog is a "multimedia interactive poster" in which people can "express ideas with ease by combining images, graphics, audio, video and text on one digital canvas." (<http://edu.glogster.com/?ref=com $>$ )
} 
FIGURE 3 - Activity 1 from Day 1 of the Hands-on Project

\section{ESTABLISHING OBJECTIVES (group activity)}

1. Within your groups, fill in the chart below with information about your project. This outline is supposed to guide you throughout the week while working on your project.

\section{PROJECT OUTLINE}

Our project theme(s):

What do we warn to share?

- PS. remember your themess] mist the melated to edicricen

What do we have to shave in terms of expertise?

Why is it important for our aublence?

Our Glogster (virtual poster) goal(s)

What are our intentions when creating our vitual poster?

Our audience:

Who do we want to reach wht our production?

Resources we may need:

What kind $o f$ materid/hesources wit we use?

How many resources will we aghly to this composition?

What is their furction in the production?

Information we may make use of:

What kind of information is important to achiene our goak with this glogster?

Where should we look for it?

Ave there trustworthy sources that we can rely on this subject?

Roles each of us will take

What are my strorg points which may be useful for this task?

information searcher. pictures

finder and designer, writer.

Which roles wall I accept as a challenge to myself demonserating

editoc, among others?

FIGURE 4 - Activity 1 from Day 2 of the Hands-on Project

\section{DAY 2}

\section{START PRODUCING YOUR GLOGSTER}

1. On a piece a paper (A3) create a sketch of your Glogster.

$>$ Discuss the following questions (in English) and use them as criteria to guide you through this process

\section{PRODUCTION: CHECK LIST}

Which is the content we will cover in this poster?

How can we organize the information nicely and clearly for our audience?
( ) covered ( ) needs revising

( ) covered ( ) needs revising 
The workshop also aimed to promote collaborative work among students and the learning of practices that focused on sharing knowledge and skills (technological and linguistic). It also proposed that students collaborated through digital literacy practices - such as the design of a digital poster and the assessment of the rhetorical conditions that such digital practice require - and through the use of English.

In these activities, the students were positioned more as knowledge producers who use different modes afforded by digital media (ex. still and moving images, sound tracks, graphic elements, etc.). The active role assigned to the students is represented by the fact that they could choose their own path in relation to which content to explore, the perspectives they aimed to represent, and the values they intended to disseminate or contest through their digital poster. In this sense, digital technology has been foregrounded as socially and culturally constructed tools that allow more active participation of learners in the production of knowledge. Moreover, the didactic proposal has dealt with the technologies as part of individuals' choices and engagements that can be challenged and adapted according to the users' needs.

In relation to how the digital tools have been represented in the proposal, we can point to both local and global awareness raising perspectives. The local awareness is considered when students reflect upon their knowledge and access. The global awareness when they consider who their audience might be for their specific glog and their use of the English language to reach a wider audience through their productions. In addition, the participants have been encouraged to choose different themes and issues, explored simultaneously in different workshops. As a result, the glogs students produced represented plural perspectives and defended various values, according to their interests.

The use of glogs allowed students to share knowledge and information they had gathered, remixed, created or recreated. The hands-on project's focus on engaging a specific audience and on using multimodal choices available to them, on the basis of the students' expertise and desires, has broadened their possibilities of action and interactions beyond the formal learning space walls. From this perspective, the students are represented in the proposal as social accountable actors, as we can see in image 1, when the project is outlined (ex. "What are our intentions when creating our virtual poster?", "How many resources will we apply to this composition?" What kind of information is important to achieve our goals with this glogster?'). 


\section{The exploration and engagement in meaning-making practices}

Generally, the activities proposed in the hands-on workshop attempted to foster the development of students' linguistics and multimodal repertoires to produce new texts and participate in Discourses (GEE, 2015) mediated by the digital practice of producing glogs. Students had not only to assess the rhetorical conditions of a specific communicative situation but also needed to understand the different stakes at value when putting forward their perspective on their chosen issue.

Such a view relies on sociocultural views of literacy (STREET, 1984; GEE, 1991; LANKSHEAR \& KNOBEL, 2011) in which language use is embedded into the social contexts of which they arise, are part of and constitute. Although there are no activities that explicitly explore the use of semiotic resources from different modes, the nature of glogs demands from students an appreciation of the kind of materials, resources and the functions such semiotic resources might have in their production (see Figure 3). In this sense, the proposal attempted to embody digital literacies as situated meaning-practices mediated by digital technologies.

There were opportunities for learners to understand and question how different modes are assembled to produce certain meanings. This is evident, for example, in the Project outline activity from Figure 3, when students are prompted to think about the purposes and functions for producing a glog (ex. "What are our intentions when creating our virtual poster?", "How many resources will we apply to this composition?", What kind of information is important to achieve our goals with this glogster?").

Another moment where students are prompted to assess the affordances different modes might offer them to produce certain meanings is the check-list activity from Figure 5. Mainly in the first item of the checklist, there are activities to promote an awareness towards the use of different modes to engage in multimodal meaning-making practice through the use of questions to force students to think about such choices (ex. Where should the images go in order to create a pleasant layout as well as to contribute to the meaning making process?).

The activities also encouraged individuals to collaborate and participate in knowledge production. There were many opportunities for learners to collaborate with each other. First, they collaborate constantly while producing their glogs. The production of glogs in groups also prompts students to negotiate different perspectives and potential conflicting issues that might emerge in such a process. Next, as can be seen in Figures 
5 and 6, students are asked to share their sketch with a different group. Such an activity is important because it encourages learners to engage in different types of participation that generally differ from the traditional organization of language classes. In the hands-on project, students have an active participation through group collaboration through the production of their glogs and a responsive participation when they are questioned about the resources they have used. Such activities are in accordance to Wenger's view of leaning in which learning has to do with being active participants in practices and constructing identities in relation to them.

FIGURE 5 - Check-list activity, from Day 2 of the Hands-on Project

\section{PRODUCTION: CHECK LIST}

\begin{tabular}{|c|c|c|}
\hline $\begin{array}{l}\text { Where should the images go in order to create a } \\
\text { pleasant layout and also to contribute to the meaning } \\
\text { making process? }\end{array}$ & ( ) covered & ( ) needs revising \\
\hline Will we place any videos? & ( ) covered & ( ) needs revising \\
\hline $\begin{array}{l}\text { Where should they go, considering the same aspects } \\
\text { mentioned in the images setting? }\end{array}$ & ( ) covered & ( ) needs revising \\
\hline $\begin{array}{l}\text { Did we check on the video quality and appropriateness } \\
\text { in terms of size? }\end{array}$ & ( ) covered & ( ) needs revising \\
\hline $\begin{array}{l}\text { Where is the proper place for our text in this visual } \\
\text { poster? }\end{array}$ & ( ) covered & ( ) needs revising \\
\hline $\begin{array}{l}\text { Are the language resources applied correctly and the } \\
\text { message clearly stated? }\end{array}$ & ( ) covered & ( ) needs revising \\
\hline $\begin{array}{l}\text { Did we work hard on bringing accurate information and } \\
\text { trustworthy sources? }\end{array}$ & ( ) covered & ( ) needs revising \\
\hline Did we acknowledge the sources property? & ( ) covered & () needs revising \\
\hline $\begin{array}{l}\text { Did we choose the format acoording to the } \\
\text { communicative situation we are about to engage in? }\end{array}$ & ( ) covered & ( ) needs revising \\
\hline $\begin{array}{l}\text { In this situation are we allowed to use our own style? } \\
\text { Which one should it be? }\end{array}$ & ( ) covered & ( ) needs revising \\
\hline $\begin{array}{l}\text { Which colors will we apply in order to create a visual } \\
\text { harmony? }\end{array}$ & ( ) covered & ( ) needs revising \\
\hline
\end{tabular}

2. Share your sketch with a different team.

> The teams will evaluate each other's production, based on the checklist above, in order to provide them with feedback; so if necessary, make notes to explain your position. 
FIGURE 6 - Check-list activity, from Day 3 of the Hands-on Project

\section{DAY 3}

\section{On a piece a paper (A3) create a sketch of your Glogster.}

Discuss the following questions (in English) and use them as critena to guide you through this process.

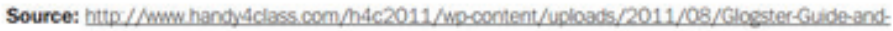
criteriasheet:2011.121 odit

2. Visit at least 3 other glogsters on the platform and analyze them using the criteria above.

\section{EVALUATION SYNTHESIS}

\section{GLOGSTER 1}

GLOGSTER 2

GLOGSTER 3

The activities proposed in the workshop create dispositions towards imagining alternative worlds by providing students with opportunities to challenge existing worldviews and by encouraging them to envision alternative practices. Such knowledge expansion can be noticed by the very fact that the proposal aims to provide students with access to new knowledge and tools (how to produce a glog), new ways of thinking (questioning, organizing ideas, evaluating them) and new ways of acting (working collaboratively). Such practices contrast directly with traditional practices in language learning pedagogies that focus solely on memorizing and producing decontextualized language structures. They also challenge students' views of what learning a language entails. From the perspective that language education involves not only learning 'a language' but also entails the changing of practices, identities and representations in relation to the world, the envisioning of an alternative practice is also seen here by the action of using English in order to communicate globally by sharing their worldviews and what it has produced locally. 


\section{The embodiment and performance of different identities}

Some of the elements discussed in sections 3.1 and 3.2 are replicated when we consider the identities students have been prompted to embody and perform by the didactic proposals. Such layering among the different principles - tools, meaning-making practices and identities - are because all of them are interrelated, and we only separate them for analytical purposes.

We consider learners as active meaning-makers that engage in certain communicative events and that can use digital literacy practices to enhance their possibilities of social participation. In the hands-on activities, it is possible to point out many opportunities in which students are prompted to engage in digital literacies (see Figures 3, 4, 5 and 6).

As for the opportunities for learners to understand digital literacy practices as inherently social and political, an intriguing conundrum emerges from the didactic proposal. On the one hand, the activities were able to encourage learners to express and share their own understandings of the world and to engage in digital language practices (see Figure 3). In this sense, learners had the opportunity to embody and perform the identities they aspired to achieve in relation to how to present a contemporary issue through glogs. On the other hand, the hands-on project lacked sustained opportunities for learners to perform identities of a more political and critical orientation. This aspect is not explicitly explored in the hands-on project, although it was explored in other workshops. Some examples of this attempt to involve students in a more critical/political discussion can be seen in Figures 7 and 8. Learners are prompted to engage in Discourses (Gee, 2015) of environmental preservation through the proposed questions. Similarly, the use of YouTube videos to trigger learners' critical appreciation and stance-taking in the activities also attempted to foster the performance of more politically oriented identities. 
FIGURE 7 - Activity from the Workshop The Environment and You

\section{CHANGING THE WAY YOU THINK ABOUT THE ENVIRONMENT}

\section{Discuss in groups}

a) How responsible do you think you are for the protection of the enwironment?

b) Do you think humans have been destroying our planet? Why?

c) Have you ever heard of WWF? What does it stand for?

2. You'll watch 2 PSAs produced by WWF. Watch, analyze them and answer the questions below

, PSA 1 - htto://voutube/s JlmohnoNY

, PSA 2 - htto://voutube/ERKOWS3hatu

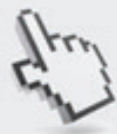

FIGURE 8 - Activity from the Workshop Let's talk about sustainable agronomy

2. Now let's talk about what you already know.

- What do you know about the food you eat?

- Do you care about where it comes from?

- Who is affected by your food choices?

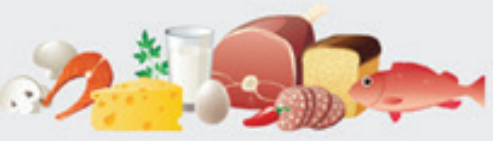

20. Woikshop oflered to students.

As previously discussed, the material has made it possible for students to analyse their modal choices, albeit in an unstructured way (Figures 3 and 4, for example), and has mediated learners' critical engagement in ideas, positions and values underlying digital literacy practices through different workshops (Figures 7 and 8, for example). However, it did not explore the semiotic choices as power related, or as ideologically constructed resources available in specific sociocultural configurations.

The hands-on project, and the workshops as a whole, have rarely fostered learner's active reflection of their epistemic views and normalized assumptions in regard to the core issues and topics. Although they were encouraged to choose the resources and themes of their projects, the critical 
positioning was somehow secondary in the material instruction and did not provide learners with sustained opportunities to critically question their own stance-making positions in digital literacy practices.

Overall, the strongest point of the didactic proposal was to connect the learners to their new role, as co-producers of their digital literacy "curriculum". In other words, they were given the responsibility to choose the resources they wanted to learn how to use, the themes they were interested in learning/exploring, and they were free to choose which roles they were willing to perform in these social interactions. In this perspective, we may claim that our language perspective is heading toward a sociocultural approach (HEATH, 1983; STREET, 1984, 2009; GEE, 1991). Nonetheless, the didactic proposal would benefit immensely from more sustained opportunities for learners to engage in the ideological dimension inherent to digital literacy practices. More semi-structured opportunities for learners to engage in recursive and reflexive thinking on the identities and stances they perform when engaging in digital literacies would also lead the didactic proposal to being more attuned to the principles of sociocultural theory.

\section{Final Remarks}

The incorporation of digital technologies in language learning pedagogies invites language teachers and researchers to rethink the language classroom beyond pedagogical practicalities, such as ways to better integrate digital technology in the existing language education curricula. Digital technology use for language learning provides language teachers and researchers with opportunities to strengthen the theoretical foundations that support their professional practices. Similarly, digitally-based language learning pedagogies provide language educators with challenges related to the reasons why individuals learn additional languages and with challenges to find ways to not be swallowed by the latest technological developments. Digital technologies emerge and are taken up as part of socially and culturally shaped struggles inherent to the globalised and unequal societies of which they are an integral part. In this sense, language learning pedagogies that aim to take advantage of digital technologies' social and participatory capabilities need to link such attempts to reflexive and critical dispositions that do not celebrate nor vilify what digital technologies can be used for contemporaneously. 
In this paper, we have detailed the foundations for supporting digitallybased language learning pedagogies from a sociocultural perspective. We have discussed the ways in which digital technologies can be conceptualised, and advocated for digitally-based language education that articulates the personal, the social and the critical dimensions of meaning-making practices through different modes. Our proposal is based on three main overarching building blocks: the tools, the meaning-making practices and the identities that constitute digital literacy practices. Such building blocks have been detailed through a series of principles and questions that can offer language educators with theoretical guidelines for the production, assessment and redrafting of digitally-based language learning pedagogies.

Such principles have emerged from our own experience with digitallybased language learning through an immersion program for high school students that took place in 2012 and 2013. We used the principles as lenses to amplify what opportunities the didactic proposal developed for the immersion program offered learners and the weaknesses that the same proposal presented in relation to the incorporation of digital technology in language learning. The findings from our analysis point out that the didactic proposal offers a number of opportunities for learners to engage in digital literacy practices through various digital tools. The choice of glogs, multimodal digital posters that embody the social, collaborative and participatory affordances of digital technology, has proved to be meaningful and adequate to develop learners' semiotic resources in a digital and multimodal globalised world for English language learning. However, the findings also pointed to the lack of deliberate and analytical opportunities for learners to question their own assumptions and stance-making in the world through digital literacies. Such a weakness points to the need for digitally-based language pedagogies to be constantly assessing the situated and partial nature of language curricula that incorporate digital technology. It also points to the challenges language educators face to explore the ideological nature of digital literacy practices in their own professional practices.

Thus, from our standpoint, the theoretical contribution of this paper was the proposal of analytical principles, which are coherent to a learning and technological sociocultural approach. We hope such principles collaborate to the design of alternative situated practices mediated by technology. 


\section{References}

ARAÚJO, J. C.; DIEB, M. (Org.). Letramentos na web: gêneros, interação e ensino. Fortaleza: Edições UFC, 2009.

ARAÚJO, J. C.; LIMA, S. de C. Letramento digital em ambiente virtual de aprendizagem: descrição das práticas de leitura e escrita promovidas por propostas de atividades no curso de Letras/Inglês. In: ARAÚJO, J. C.; DIEB, M.; LIMA, S.C. (Org.). Linguas na web: links entre ensino e aprendizagem. Ijuí: Editora Unijuí, 2010. p. 243-266.

BALADELI, A. P. D.; FERREIRA, A. J. Ciberespaço e educação: proposições acerca dos letramentos digitais. Imagens da Educação, Maringá, v. 2, n. 2, p. 67-73, 2012.

BRAGA, D. B. Tecnologia e participação social no processo de produção e consumo de bens culturais: Novas possibilidades trazidas pelas práticas letradas digitais mediadas pela internet. Trabalhos em Linguistica Aplicada, Campinas, v. 49, n. 2, p. 373-391, 2010. Available at: <http://www.scielo.br/scielo.php?script=sci_ arttext\&pid=S0103-18132010000200005\&lng $=$ pt\&nrm $=$ iso\&tlng $=p t>$. Retrieved on: 27 Sept. 2013.

BRAGA, D. B. Developing critical social awareness through digital literacy practices within the context of higher education in Brazil. Language and Education, Francis \& Taylor Online, v. 21, n. 3, p. 180-196, 2007.

BRAGA, D.; VOVIO, C.L. Uso de tecnologia e participação em letramentos digitais em contextos de desigualdade. In: BRAGA, D. (Org.). Tecnologias digitais da informação e comunicação e participação social. Sao Paulo: Cortez, 2015. p. 33-67.

BUCKINGHAM, D. Beyond technology: Children's learning in the age of digital culture. Cambridge: Polity, 2007.

BUCKINGHAM, D. Making sense of the 'Digital Generation': Growing up with digital media. Self \& Society, Taylor and Francis Online, v. 40, n. 3, p. 7-15, 2013. Available at: <http://www.tandfonline.com/doi/abs/10.1080/03060497.2013.1 1084274>. Retrieved on: 15 Jan. 2015.

BUZATO, M. E. K. Letramentos digitais e formação de professores. In: III Congresso Ibero-Americano EducaRede, 2006, São Paulo. CENPEC. p. 80-86.

BUZATO, M. E. K. Cultura digital e apropriação ascendente: Apontamentos para uma educação 2.0. Educação em Revista, Belo Horizonte, v. 26, n. 3, p. 283-304, 2010. Available at: <http://www.scielo.br/scielo.php?script=sci_arttext\&pid=S010246982010000300014\&lng=en\&nrm=iso\&tlng=pt>. Retrieved on: 14 Nov. 2012. 
BUZATO, M.E.K. Letramento e inclusão: do estado-nação à era das TIC. Revista de Documentação de Estudos em Linguistica Teórica e Aplicada, São Paulo, v. 25, n. 1, p.1-38, 2009. Available at: <http://www.scielo.br/scielo.php?script=sci_ arttext\&pid=S0102-44502009000100001\&lng=en\&nrm=iso\&tlng=pt $>$. Retrieved on: 05 Mar. 2011.

FERREIRA, A. J. Identidades sociais, letramento visual e letramento crítico: imagens na mídia acerca de raça/etnia. Trabalhos em Linguística Aplicada, Campinas, v. 51, n. 1, p. 193-215, jun. 2012. Available at: <http://www.scielo.br/scielo.php?script=sci_ arttext\&pid $=$ S0103-18132012000100010\&lng $=$ pt\&nrm=iso $>$. Retrieved on: 18 Jan. 2014.

GAMERO, R.; EL KADRI, M. S.; GIMENEZ, T. Material didático para educação tecnológica de professores de inglês: uma experiência no âmbito do programa 'Novos Talentos'. Linguagem \& Ensino, Pelotas, v. 15, n. 1, p. 181-212, 2012.

GEE, J. P. Social linguistics and literacies: Ideology in Discourses. 5. ed. London: Routledge, 2015.

GEE, J. P. Social linguistics and literacies: Ideologies in discourses. 1st ed. London: Falmer Press, 1990.

HEATH, S. B. Ways with words: Language, life, and work in communities and classrooms. New York: Cambridge University Press, 1983.

JENKINS, H. Convergence culture: where old and new media collide. rev. New York: New York University Press, 2008.

JONES, R. H.; HAFNER, C. A. Understanding digital literacies: A practical introduction. New York: Routledge, 2012.

JORDÃO, C. M. As lentes do discurso: Letramento e criticidade no mundo digital. Trabalhos em Linguística Aplicada, Campinas, v. 46, n. 1, p. 19-29, jun. 2007. Available at: <http://www.scielo.br/scielo.php?script=sci_arttext\&pid=S0103$18132007000100003 \& \operatorname{lng}=\mathrm{pt \& nrm}=$ iso $>$. Retrieved on: 06 Jun. 2012.

KRESS, G. Multimodality: A social semiotic approach to contemporary communication. New York: Routledge, 2010.

KUMARAVADIVELU, B. Toward a Postmethod Pedagogy. TESOL Quarterly, Wiley Online Library, v. 35, n. 4, p. 537-560, 2001. Available at: <http://dx.doi. org/10.2307/3588427>. Retrieved on: 27 Sept. 2013.

LANKSHEAR, C.; KNOBEL, M. New literacies: Everyday practices and social learning. 3. ed. Berkshire: Open University Press, 2011.

MILLER, V. Understanding digital culture. Los Angeles: Sage, 2011. 
MOITA LOPES, L.P. Os novos letramentos digitais como lugares de construção de ativismo político sobre sexualidade e gênero. Trabalhos em Linguística Aplicada, Campinas, v. 49, n. 2, p. 393-417, 2010.

MONTE MÓR, W. Foreign languages teaching, education and the New Literacy Studies: expanding views. In: GONÇALVES, G. R.; ALMEIDA, S. R. G.; PAIVA, V. L. M. O; RODRIGUES-JUNIOR, A. S. (Org.). New challenges in language and literature. Belo Horizonte: Faculdade de Letras da UFMG, 2009. p. 177-189.

MONTE MOR, W. Linguagem digital e interpretação: perspectivas epistemológicas. Trabalhos em Linguística Aplicada, Campinas, v. 46, n. 1, p. 31-44, jun. 2007. Available at: <http://www.scielo.br/scielo.php?script=sci_arttext\&pid=S0103$18132007000100004 \& \operatorname{lng}=$ pt\&nrm=iso $>$. Retrieved on: 06 Jun. 2012.

PAIVA, V. L. M. O. Letramento digital através de narrativas de aprendizagem de língua inglesa. CROP, São Paulo, n. 12, p.1-20, 2007. Available at: <http://200.144.182.130/revistacrop/images/stories/edicao12/v12a01.pdf>. Retrieved on: 20 Fev. 2012.

ROJO, R. Letramentos digitais - a leitura como réplica ativa. Trabalhos em Linguistica Aplicada, Campinas, v. 46, n. 1, p. 63-78, jan./jun., 2007. Available at: <http://www. gse.uci.edu/person/warschauer_m/overview.html>. Retrieved on: 27 Sept. 2013. SELWYN, N. Looking beyond learning: notes towards the critical study of educational technology. Journal of Computer Assisted Learning, Wiley Online Library, v. 26, n. 1, p. 65-73, 2010. Available at: <http://dx.doi. org/10.1111/j.1365-2729.2009.00338.x>. Retrieved on: 27 Sept. 2013.

SNYDER, I. Shuffling towards the future: The enduring dominance of book culture in literacy education. In: BAYNHAM, M.; PRINSLOO, M. (Org.). The future of literacy studies. London: Palgrave Macmillan, 2009. p. 141-159.

STREET, B. Literacy in theory and practice. Cambridge: Cambridge University Press, 1984.

STREET, B. New Literacy Studies. In: GRENFELL, M.; BLOOME, D. et al. (Org.). Language, ethnography and education: Bridging New Literacy Studies and Bourdieu. New York: Routledge, 2013. p. 27-49.

VAN DIJK, J. The network society. 3. ed. London: Sage, 2012.

WARSCHAUER, M. Researching Technology in TESOL: Determinist, Instrumental, and Critical Approaches. TESOL Quarterly, Wiley Online Library, v. 32, n. 4, p. 757-761, 1998. Available at: <http://dx.doi.org/10.2307/3588010>. Retrieved on: 27 Sept. 2013.

Data de submissão: 07/02/2017. Data de aprovação: 19/10/2017. 